THE WABASH CENTER

JOURNAL oN TEACHING
BOOK REVIEW

\section{Student-Driven Learning Strategies for the 21st Century Classroom}

\author{
Nor Aziah Alias and Johan Eddy Luaran, editors \\ Hershey, PA: IGI Global, 2017 \\ (xxiii + 434 pages, ISBN 1522516891, \$102.00)
}

Reviewed By

S. Brian Stratton

University of North Carolina

at Pembroke
The essays collected in this book grew out of the editors' experience running a 2015 symposium on learner-driven learning. As with most edited volumes, the reader will find essays of differing quality and relevance; obtaining a copy from a library to gauge its usefulness would be preferable to purchasing the book.

The preface distinguishes "student-driven" learning from student learning and self-directed learning for it "requires the motivation, the internal drive to initiate and to propel one's learning into a more personalized space at a personal pace" (xix). Whether this is a real distinction with a difference is not clear to this reviewer, but it does at least allow one to place the book within a broader scholarly context on pedagogy. The target audience is higher-learning educators and it is intended for reading and reference, though it is probably best suited for use as a reference work.

The diversity of topics treated is impressive. The chapters are comprehensive and treat higher education from undergraduate to doctoral levels. Essays discuss classroom, blended, and online class environments. Individual and collaborative learning are both addressed. Traditional and non-traditional students receive attention as do universities and community colleges. The book strongly represents global perspectives with many institutions from around the world being the subject of the essays. Suggestions for improving learning across an impressive array of academic disciplines are made. The essays dealing with STEM education are strong, and many of the essays contain helpful ways for integrating multiple types of student-driven learning into the classroom. However, despite the impressive inclusiveness of the book no essays treat issues of gender, race, sexuality, or students with special needs.

The book presents twenty-two chapters in three main sections. The first section discusses the parameters for the design of student-driven learning, the second strategies and approaches in student-driven learning, and the third supporting student-driven learning. Useful information is found in all three sections, but the third may be of most interest to those involved in actual practice of teaching since three of the chapters are written with the teacher's role in mind. The final chapter addresses an often-overlooked subject that is frequently on students' minds, if not on educators' - career forecasting. The author makes a good case for including this skill within the education curriculum.

The book could benefit from more careful editing and proofreading as it contains several typographical errors and subjectverbs that do not agree. In addition, educational jargon is heavily used so some readers may find some essays very technical to read. Still this book will be useful to those interested in the specific topics the essays address. 